\title{
Impact of Organic Foliar Nutrition and its Efficacy on Sustainable Production of Rice
}

\section{R Raman* and R Krishnamoorthy}

Department of Agronomy, Faculty of Agriculture, Annamalai University, Tamilnadu, India

*Corresponding Author: R Raman, Department of Agronomy, Faculty of Agriculture, Annamalai University, Tamilnadu, India.

Received: February 25, 2019; Published: September 16, 2019

DOI: 10.31080/ASAG.2019.03.0647

\begin{abstract}
Currently the challenge before us is to achieve and sustain growth rates high enough to feed the enormous population without degrading the environment. Soil fertility is a major factor to consider for enhancing the crop yield. Mineral fertilizers is undoubtedly the fastest way to boost crop growth but total dependence on it could lead to increased weed pressure, acidification and soil organic matter depletion. Now, our research is focused on evolving ecologically sound, biologically sustainable and economically viable technology. Field experiment was conducted from September 2016 to January 2017 at Annamalai University Experimental Farm, Annamalai Nagar, India with an objective to evaluate the organic source of nutrients spray on the growth and yield of rice. All the treatments were found to significantly influence the growth and yield components and yield of rice.
\end{abstract}

Keywords: Foliar Nutrition; Vermiwash; Panchagavya; Biogas Slurry

\section{Introduction}

Rice (Oryza sativa) is the most important food crop and almost half of the world population eats rice. It is grown in about 150 million hectares of land area with a total annual production of nearly 350 million tones. In India as it is cultivated in an area of $42.7 \mathrm{~m}$ ha- 1 with a production of $85.5 \mathrm{mt}$. National commission on Agriculture has estimated that the food requirement for the burgeoning Indian population during 2025 A.D. would be around 225 MT to meet this challenge, the present productivity per unit area is to be necessarily enlarged. The use of organic manures in augmenting soil fertility and crop productivity is well known. Rice occupies a pivotal position in relation to food security in India. Future of food security in this region will depend on its ability to improve productivity continuously on an ecologically sustainable basis. The application of chemical fertilizers has undoubtedly increased the production at the same time it leads to the accumulation of hazard on pollutants and undesirable effect on soil sustainability in the long term. In India, there is a good scope for utilizing agricultural wastes. The role of organic manures would be extremely important from sustainability point of view. It is therefore necessary to judiciously manage the inflow of organic nutrients through foliar application [1]. Foliar fertilization is an economical way of supplementing the plant nutrients when they are in lack or unavailable in the soil. One advantage of foliar nutrition is that it often brings about immediate improvement in plant health and growth. Biogas slurry, cow dung slurry, vermiwash and panchagavya increased the growth and yield of crops. Information was lacking on the effect of organic foliar nutrient. Hence the present investigation was taken up.

\section{Materials and Methods}

Field experiment was carried out at the Experimental Farm, Department of Agronomy, Annamalai University during September 2016 to January 2017. The soil was clayey loam in texture with low available nitrogen $\left(14.0 \mathrm{~kg} \mathrm{ha}^{-1}\right)$, medium available phosphorus (25 $\left.\mathrm{kg} \mathrm{ha}^{-1}\right)$ and high available potassium ( $\left.375 \mathrm{~kg} \mathrm{ha}^{-1}\right)$. The experiment was laid out in randomized block design (RBD) with three replications. The experiment consists of thirteen treatments viz., no foliar spray control $\left(\mathrm{T}_{1}\right)$, vermiwash 2 percent $\left(\mathrm{T}_{2}\right)$, vermiwash 4 percent $\left(\mathrm{T}_{3}\right)$, vermiwash 6 percent $\left(\mathrm{T}_{4}\right)$, Panchagavya 2 percent $\left(\mathrm{T}_{5}\right)$, Panchagavya 4 percent $\left(\mathrm{T}_{6}\right)$, Panchagavya 6 percent $\left(\mathrm{T}_{7}\right)$, biogas slurry 2 percent $\left(\mathrm{T}_{8}\right)$, biogas slurry 4 percent $\left(\mathrm{T}_{9}\right)$, biogas slurry 6 percent $\left(\mathrm{T}_{10}\right)$, cow dung slurry 2 percent $\left(\mathrm{T}_{11}\right)$, cow dung slurry 4 percent $\left(\mathrm{T}_{12}\right)$ and cow dung slurry 6 percent $\left(\mathrm{T}_{13}\right)$.

The organic foliar nutrients such as cow dung slurry and biogas slurry collected from the Experimental farm. The vermiwash is one of value added product from the vermicompost unit and it is an extract of earthworm body secretion and other body discharge, which is rich in plant nutrients in soluble form, plant growth hormones and antibiotics. Panchagavya, a mixture of indigenously available bio products mainly comprising of cow's milk, dung, urine, ghee, curd, sugarcane juice, banana and tender coconut water. The foliar nutrients applied as per the treatment schedule two times, first spray at active tillering stage and second spray at 50 percent flowering time. 


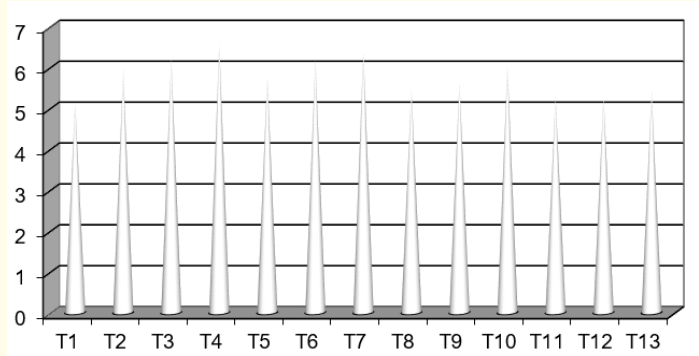

Figure 1: Effect of Foliar Nutrition on grain yield of rice tones/ha. $\mathrm{X}$-axis treatment; Y-axis rice yield $\mathrm{t} \mathrm{ha}^{-1}$.

\section{Results}

All the growth components like tiller number hill ${ }^{-1}$, leaf area index and dry matter production were significantly influenced by the treatments. Among the treatments, foliar application of vermiwash 6 percent recorded the maximum number of tillers, LAI and DMP of rice crop. This was followed by foliar application of Panchakavya 6 percent. The control treatment recorded the least value of growth attributes.

In respect to the yield and yield attributes of rice, foliar nutrition of vermiwash 6 percent $\left(\mathrm{T}_{4}\right)$ registered the higher number of panicles, more grains per panicle ${ }^{-1}$ and grain yield. The next best

\begin{tabular}{|l|c|c|c|c|c|}
\hline Treatment & Plant height cm & Tillers hill $^{-1}$ & Dry Matter Production & No. of panicles nil $^{\mathbf{1}}$ & No. of filled grains panicle $^{\mathbf{1}}$ \\
\hline $\mathrm{T}_{1}$ & 74.27 & 8.34 & 6.71 & 4.31 & 88.92 \\
\hline $\mathrm{T}_{2}$ & 85.19 & 10.62 & 8.05 & 5.60 & 91.08 \\
\hline $\mathrm{T}_{3}$ & 89.57 & 11.50 & 8.61 & 6.14 & 92.19 \\
\hline $\mathrm{T}_{4}$ & 93.94 & 12.37 & 9.14 & 6.68 & 92.79 \\
\hline $\mathrm{T}_{5}$ & 83.27 & 10.18 & 7.78 & 5.35 & 90.90 \\
\hline $\mathrm{T}_{6}$ & 89.53 & 11.47 & 8.59 & 6.10 & 92.03 \\
\hline $\mathrm{T}_{7}$ & 91.73 & 11.93 & 8.87 & 6.40 & 93.23 \\
\hline $\mathrm{T}_{8}$ & 77.70 & 9.31 & 7.25 & 4.86 & 90.07 \\
\hline $\mathrm{T}_{9}$ & 80.86 & 9.76 & 7.52 & 5.10 & 90.44 \\
\hline $\mathrm{T}_{10}$ & 87.36 & 11.04 & 8.32 & 4.84 & 91.46 \\
\hline $\mathrm{T}_{11}$ & 76.42 & 8.79 & 6.97 & 4.56 & 89.45 \\
\hline $\mathrm{T}_{12}$ & 76.47 & 8.82 & 6.99 & 4.59 & 89.59 \\
\hline $\mathrm{T}_{13}$ & 78.61 & 9.27 & 7.23 & 4.83 & 90.01 \\
\hline
\end{tabular}

Table 1: Effect of Foliar Nutrition through organic Source on Growth and Yield Attributes of Rice.

was the foliar application of panchakavya 6 percent. The least yield and yield components were recorded under control $\left(\mathrm{T}_{1}\right)$.

\section{Discussion}

The research results revealed that foliar application of vermiwash 6 percent increased all the growth and yield of attributes and yield of rice. The beneficial effect of vermiwash on plant growth might be due to the presence of several macro and micro nutrients available in the vermicast and their secretions in considerable quantities. It is in agreement with the findings of Gauirlov [2] who found that the metabolites produced by earthworms could be responsible for the stimulation o plant growth.

The increased yield components due to the vermiwash application might be due to continuous supply of phosphorus in available form from vermi wash [3] and its involvement in plant system and the presence of certain growth promoting substances [4]. This was followed by foliar application of Panchakavya 6 percent. Better performance of this treatment due to application of Panchakavya that hormonizes basic elements which revitalize the growth process [5] and mainly due to the uptake of nutrients by the crop because of its proper placement in the leaves and its sufficient nutrient availability at the initial stages of crop growth.

\section{Conclusion}

Organic foliar nutrition effect was clearly evidenced by the positive influence on the growth and yield attributes of rice. Among the foliar nutrients, vermiwash and panchagavya were superior as evidenced by their contribution in augmenting more growth and yield components. Results of this investigation are a clear pointer to the farming community that the organic foliar nutrition were recommended in view of its cost effectiveness and ecological safety.

\section{Bibliography}

1. Somasundaram E., et al. "Biogas slurry and Panchakavya promising organics to reconstruct our agro ecosystem". Agrobios New Letter 11.10 (2004): 13-14.

2. Gaurilor K. "Role of earth worms in the enrichment of soil by biological active substances, Voprosy Ekologii vysshaya Shkola Moscow 7 (1962): 34.

3. Karuna K., et al. "Stimulation Effect of Earthworms, body fluid (Vermiwash) on crinckle red variety on Anthurium andrearu". Lind Crop Science 17.2 (1999): 253-257. 
4. Morselli T., et al. "Response of Cobbage and cauliflower to application of vermicompost in the liquid form". Revista Cientifica Rural 4.2 (1999): 24-28.

5. Books Natarajan K. "Panchakavya Manual" Other India Press, Manusa, Goa India (2001): 33.

Volume 3 Issue 10 October 2019

(C) All rights are reserved by $R$ Raman and $R$ Krishnamoorthy . 